\title{
Evolución de 1 año de un paciente rehabilitado con implantes oseointegrados de carga inmediata después de la resección quirúrgica de un cementoblastoma: Reporte clínico
}

\section{Clinical Report: Patient's progress one year after being treated with immediate loading bone integrated implants after removal of cementoblastomas}

\author{
E.J. de Moraes ${ }^{1}$, N. Benevides Moraes², D. Farias Miranda ${ }^{3}$
}

Resumen: Se presenta un caso clínico correspondiente a un paciente con diágnostico de dos cementoblastomas, en el cual, posterior a la resección quirúrgica de ambos tumores, se rehabilitó con una prótesis sobre implantes de carga inmediata. Para esto instalaron 4 implantes, utilizando el sistema de Carga Inmediata Speed Máster (Conexão Sistema de Prótesis- São Paulo- Brazil) con la instalación de la prótesis 48 horas después de la cirugía. La evolución clínica y radiográfica fue seguida por 14 meses, comprobando que los implantes mantenían una condición adecuada

Palabras clave: Cementoblastoma; Osteointegración; Carga inmediata.
1 Head of Oral Implantology Course, Post Graduation Department, Centro Universitario Serra dos Orgãos (UNIFESO). Teresópolis, Rio de Janeiro, Brazil.

2 Scientific Initiation Program of Oral Pathology Department, Universidade Federal Fluminense (UFF). Niterói, Rio de Janeiro, Brazil.

3 Head of Oral Implantology clinic. Carabineros de Chile, Santiago, Chile.

\begin{abstract}
The authors present a clinical case of a patient with two cementoblastomas who was treated with four implants installed using Speed Master System. The prosthesis was seated 48 hours after surgery. The clinical and radiographic follow-up was performed 14 months later and it was determined that the implants were in satisfactory conditions.
\end{abstract}

Key words: Cementoblastoma; Osseointegraton; Immediate loading.

Correspondencia:

Eduardo J. Moraes

E-mail: edurjm@uol.com.br 
La osteointegración establece una nueva era para la implantología, permitiendo la utilización de implantes en la rehabilitación de maxilares edentulos con una mejor previsibilidad y una elevada tasa de éxito. El desarrollo de un protocolo quirúrgico protésico comprobado por un estudio clínico de 15 años, sumado a estudios experimentales de laboratorio, en relación a cicatrización ósea, constataron que un periodo de 3 a 6 meses sería un tiempo mínimo suficiente para obtener la osteointegración antes de someter los implantes a una carga funcional.' Entre tanto, el protocolo clásico de dos etapas para lograr osteointegración, avalado por 35 años de experiencia clínica, ha sufrido modificaciones a través del tiempo, permitiendo en ciertos casos una reducción en el tiempo de espera antes de la rehabilitación del paciente.

Diversos autores han demostrado, por medio de resultados clínicos y hallazgos histológicos, éxito en las rehabilitaciones de implantes oseointegrados sometidos a carga inmediata, esta alternativa a optimizado el tiempo de tratamiento.7,8,10,11,12,16 El sístema Branemark NOVUM fue desarrollado con el objetivo de posibilitar la instalación de la prótesis sobre implantes entre 6 a 8 horas después de la cirugía. De acuerdo con este protocolo los implantes deben ser rígidamente conectados y posicionados con precisión, siendo sometidos a carga inmediata sin alterar el proceso de osteointegración.

\section{Cementoblastoma}

El cementoblastoma benigno (CD) es un cementoma "verdadero", un raro neoplasma que representa de 1 a 6,2 \% de todos los tumores odontogénicos. Radiográficamente, más del $90 \%$ de estos tumores presentan un área radiopaca bien definida o una mezcla de masas densas asociadas alrededor de raíces dentarias. Es un tumor de crecimiento lento, que desplaza en algunos casos la cortical ósea. La Organización Mundial de la Salud (2005) clasificó al cementoblastoma como un tumor benigno derivado del mesénquima odontogénico o ectomesénquima odontogénico con o sin epitelio odontogénico. En el grupo de tumores llamados cementomas, encontramos a los cementomas periapicales y los fibromas cementificantes. El tratamiento apropiado consiste en la remoción de la lesión junto con el diente involucrado, seguido de curetaje u osteotomía periférica. Algunos autores sugieren el uso de injerto óseo o regeneración ósea guiada después de la remoción del tumor.

\section{Caso Clínico}

Paciente varón de 62 años, portador de una prótesis parcial removible bilateral en la mandíbula, soportada por los caninos inferiores, consulta por una herida en la mucosa mandibular derecha. El paciente relata haber sido sometido a una cirugía para la extracción de una pieza dentaria en esa región hace 4 meses atrás. La región intervenida no tuvo una buena cicatrización y esta condición imposibilitó el uso de la prótesis removible (Fig. 1).

Durante el examen clínico, se observa la presencia de una herida en la mucosa alveolar del lado mandibular derecho. La radiografía panorámica muestra un área radiopaca bien definida aso-
Osseo integration establishes a new era for implantology, allowing implant use in maxilla "edentula" with better predictability and a higher success rate. The development of a prosthetic surgical protocol proven by a 15 year clinical study, in addition to the experimental lab studies related to bone healing, it was verified that a 3-6 month period would be the minimum time to get Osseo integration before submitting the implants to a working load. Meanwhile the classic protocol for the 2 stage Osseo integration, guaranteed by 35 yeas of clinical experience, has been modified over time. These modifications, in some cases, allow for a reduction in wait time before patient rehabilitation.

Using clinical results and histological discoveries various authors have shown success using Osseo integrated implants subjected to immediate loading. This alternative at optimized time of treatment.7,8,10,11,12,16 The Branemark NOVUM system was developed in order to make it possible to install the prosthesis over implants 6-8 hours after surgery. In accordance with this protocol the implants should be rigidly connected and positioned with precision, being subjected to immediate loading without altering the Osseo integration process.

\section{Cementoblastoma}

Benign cementoblastoma is a "real" cementoma, a rare neoplasm that represents $6.2 \%$ of all odontogenic tumors. More than $90 \%$ of these tumors have a well defined radiographic area or a mix of dense associated masses around the dental roots. It is a slow growing tumor, which in some cases displaces the bone cortica. The World Health Organization (2005) classified cementoblastoma as a benign tumor derived from odontogenic mesenchyme or odontogenic ectomesenchyme with or without odontogenic epithelium. In the group of tumors called cementomas we find periapical cementomas and cementificant fibromas. The proper treatment consists of removal of the lesions along with the involved tooth, followed by curettage or peripheral osseotomy. Some authors suggest the use of bone grafts or guided bone regeneration after the tumor is removed.

\section{Clinical Case}

Male patient, 62 years old, beneficiary of a bilateral removable partial prosthesis in the mandible, supported by the inferior canines. He comes to consult because of a wound in the right mandible mucosa. The patient reports having surgery to remove a dental piece in this area 4 months prior. The affected region did not have good healing and this condition made it impossible to use a removable prosthesis (Fig. 1).

During the clinical exam we see a wound in the alveolar mucosa on the right mandible side. The radiograph shows a well defined radiopaque region associated with the remain- 
ciada a una raíz dentaria remanente en la región del 46 y un área radiolucida bien definida en la región periapical del canino inferior izquierdo (Fig. 2).

\section{Plan de tratamiento e Instalación de implantes}

En función de las condiciones presentadas por el paciente, fue propuesto la exodoncia del diente remanente y la resección de los tumores, instalación e implantes y una rehabilitación protésica de carga inmediata.

Aunque el motivo de consulta del paciente fue la presencia de una herida en la mucosa mandibular que imposibilitaba su función masticatoria con la prótesis removible. El tratamiento propuesto para ser rehabilitado con una prótesis fija sobre implantes instalada a las 48 horas fue aceptada por el paciente.

La cirugía consistio en una incisión supracrestal en la región anterior de la mandibula con colgajo vestibular y lingual. Luego los elementos dentarios fueron extraídos y se realizó una osteotomia rotatoria para efectuar un aplanamiento óseo de la cresta alveolar y lograr una meseta.

En relación a las condiciones presentadas por el paciente, se planificó la exodoncia del diente remanente y la resección de los tumores junto con la instalación de implantes y una rehabilitación protésica de carga inmediata.

Aunque el motivo de consulta del paciente fue la presencia de una herida en la mucosa mandibular, que imposibilitaba su función masticatoria con la prótesis removible, el paciente aceptó el tratamiento propuesto mediante a implantes oseointegrados y una rehabilitación con prótesis fija instalada a las 48 horas.

La cirugía consistió en una incisión supracrestal en la región anterior de la mandíbula despegamiento vestibular y lingual. Luego fueron extraídas las piezas dentarias y se realizó una osteotomía con fresas fisuras 701 y 702 para la remoción de un bloque óseo conjuntamente con el cementoma, luego se relleno la cavidad con biomateriales HA de hueso bovino. En la zona de instalación de los implantes con el sistema Speedy Master se realizó una osteotomía para aplanamiento de la cresta alveolar y la formación de una meseta (Fig. 3).

Una hora antes del procedimiento quirúrgico fue administrado al paciente $2 \mathrm{~g}$ de amoxicilina y $4 \mathrm{mg}$ de betametasona. En el post operatorio el paciente tomó amoxicilina $500 \mathrm{mg} 4$ veces al día durante siete días y tenoxicam 20 mg 1 vez al día por tres días y para el control de placa si indicó colutorios con solución de clorhexidina 0,12\% tres veces al día. El examen histológico reveló un tumor bien circuns-

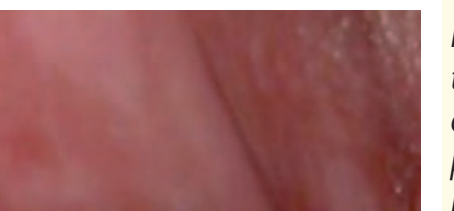

ing dental root around the 4.6 tooth. There is also a well defined radio lucid area in the periapical region of the left inferior canine (Fig. 2).

\section{Treatment plan and Installation of implants}

Based on the patient's conditions, the proposal was to remove the remaining tooth and tumors, install implants and prosthetic rehab with immediate loading.

The motive for the visit was a wound in the mandible mucosa that made chewing impossible with the removable prosthesis. The proposed treatment was rehabilitation with a fixed prosthesis over implants installed after 48 hours. The patient accepted. The surgery consists of a supracrestal incision in the anterior region of the mandible with a vestibular and lingual flap. After the dental elements were removed and a rotary osteotomy was carried out in order to flatten the bone and the alveolar crest in order to get a plateau.

In relation to the conditions presented by the patient, the exodontic was planned for the remaining tooth and the removal of tumors along with the installation of implants and prosthetic rehab with immediate loading.

Although the purpose of the patients visit was because of a mucosa mandible that made chewing impossible the patient accepted the proposed treatment based on Osseo integrated implants and rehabilitation with fixed prosthesis 48 hours later.

The surgery consisted of a supracrestal incision in the anterior region of the vestibular and lingual region. Afterwards the teeth were removed and osteotomy with drills 701 and 702 was performed to remove a bone block and a cementoma. Then the cavity was filed with biomaterials $H A$ and bovine bone. In the area were the implants were placed, osteotomy was performed with Speedy Master system to flatten the alveolar crest and to form a plateau (Fig. 3).

An hour before the surgical procedure began the patient was administered $2 \mathrm{~g}$ of Amoxicillin and $4 \mathrm{mg}$ of Betamethasone. After surgery the patient took $500 \mathrm{mg}$ of Amoxicillin 4 times a day for 7 days and Tenoxiam $20 \mathrm{mg}$ once a day for 
crito mostrando un aspecto de mosaico, con laminas densas irregulares y un tejido tipo cemento sin presencia de tejido intersticial. Presencia de tejido cementoide con cementoblastos hipercromáticos.

Como la propuesta de tratamiento consistía en la instalación de implantes sometidos a carga inmediata, se utilizó el sistema Speedy Master (Conexao Sistema de Protesis- Sao Paulo- Brasil). Este sistema esta compuesto de una plantilla quirúrgica metálica pre fabricada que debe ser fijada con micro tornillos de titanio, para

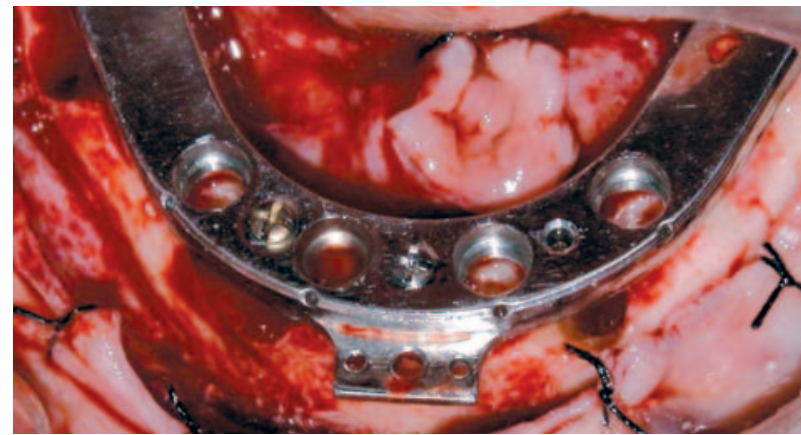

Figura 3. Fijación de guía quirúrgica metálica pre fabricada después del aplanamiento del reborde óseo remanente.

Figure 3. Metal surgical guide.
3 days. To control the plaque mouthwash with Chlorhexidine solution. $12 \%$ was prescribed 3 times a day. The histological exam discovered a well embraced tumor that had a mosaic appearance, dense irregular sheets and cement type tissue without interstitial tissue. There was cementoid tissue with hyper chromatic cementoblasts.

Proposed treatment consisted of the installation of implants subjected to immediate loading, so we used the Speedy Master system (Conexao Sistema de Prosthesis, Sao Paulo Brazil). This system is made of a premade metal surgical screen that should be fixed with titanium micro screws, to perforate the implant floor in the pre established areas. Vasconcellos et al. ${ }^{20}$ had good results with the newly proposed immediate loading protocol.

After the implementation of the beds, 4 implants ( 3.75 $\mathrm{mm}$ diameter and $13 \mathrm{~mm}$ length) were installed. Their design was screw-like and the surface was treated with acid and internal hexagon, anchored with a $45 \mathrm{Ncm}$ torque in the interforaminal region.

The conic pillars were connected to the implants with a 20 $\mathrm{Ncm}$ torque. The pillars were installed by impression and the suture was carried out in the soft tissue with 5-0 mono nylon.

\section{Post operative register and prosthetic protocol}

After suturing the pillars were ferulized with acrylic resin (Pattern Resin, GCAmerica, Alsip, IL) and later they were joined to the multi purpose groove this groove, apart from being a surgical groove that helps obtain intermaxilla registers like: vertical dimension, occlusion and position of the implants). It also injected Speedex condensed silicone (Vigodent, Rio de Janiero, Brasil) under the resin connected to the groove, to establish a reference for the soft tissue.

Once removed multipurpose groove was removed they installed the titanium components over the pillars, under absolute isolation with a rubber dam. The metallic superstructure, premade by the Speedy Master with Panavia F (Kuraray Co, Kurashiki, Japan) was cemented over the titanium components.

The metallic superstructure with united components was removed and sent to the lab so that the final prosthesis could be made. Afterwards the protective covers were installed on the pillars.

From the registers established by the multipurpose acrylic groove a model was made out of Velmix type IV plaster (Kerr, Orange, CA). The master model was placed on the semi mente a los pacientes con exámenes clínicos hasta completar 1 año. 
Al remover la prótesis los implantes no presentaron signos de movilidad o de inflamación. Para la revisión de cada implante se utilizó los criterios propuestos por Albrektsson y Zarb ${ }^{1}$ en relación a Indice de sangramiento, control radiográfico y test de contra-torque (10 Ncm) (Figs. 5 y 6).

\section{Discusión}

El caso presentado mostró características diferentes de las condiciones clínicas de rutina, pues el paciente presentaba un tumor odontogénico y fue rehabilitado con implantes sometidos a carga inmediata asociada a una cirugía de resección del tumor.

El tratamiento utilizado en este caso fue la resección quirúrgica del tumor con extracción de los dientes en relación a la lesión, seguido de un curetaje y osteotomía periapical de acuerdo con la propuesta de Brannon et al. Otros autores ${ }^{5}$, sugieren la regeneración ósea guiada (ROG) después de la remoción de los fragmentos del cementoblastoma. En el caso relatado en este articulo no fue usada ROG obteniendo un resultado satisfactorio.

El protocolo protésico utilizado fue el Sistema de Carga Inmediata Speed Master, siguiendo el protocolo propuesto por Vasconcellos et al, que esta de acuerdo a los principios presentados por el Sistema Branemark Novum.

A pesar de algunas diferencias existente entre los protocolos, el concepto básico de prevención del micromovimiento de los implantes citado por Skalak fue respetado. Todos los implantes fueron instalados con un anclaje inicial de $45 \mathrm{Ncm}$ y ferulizados con una supraestructura rígida.

La cementación de la supraestructura de titanio sobre los componentes, se basó en los estudios presentados por Jimenez-Lopes ${ }^{12}$ y Strub et al. ${ }^{17}$ de pasividad protésica. Jimenez-Lopes ${ }^{9}$ mostró la eficacia y resistencia del cemento panavia para fijar los componentes de la prótesis. Los estudios de Alba Junior et al $^{2}$ corroboran los resultados de esos autores. Algunos autores han comprobado clínicamente el éxito de la propuesta de cementación de la supraestructura sobre los componentes de titanio. ${ }^{10,14,15}$

La presentación de este caso ha demostrado que la utilización de implantes oseointegrados de carga inmediata es posible de efecde la prótesis. pués de 14 meses. months.

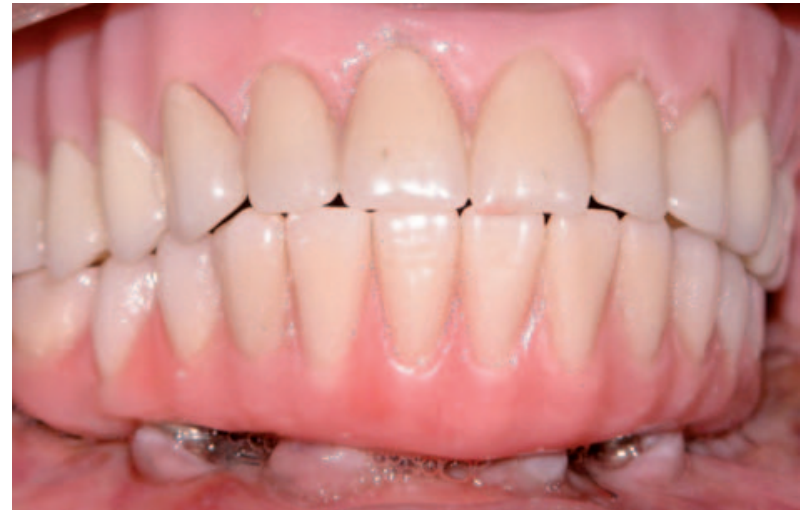

Figura 4. Condición bucal después de 1 semana de instalación

Figure 4. Fixation of the pre made metal surgical groove after the flattening of the remaining bone ridge.

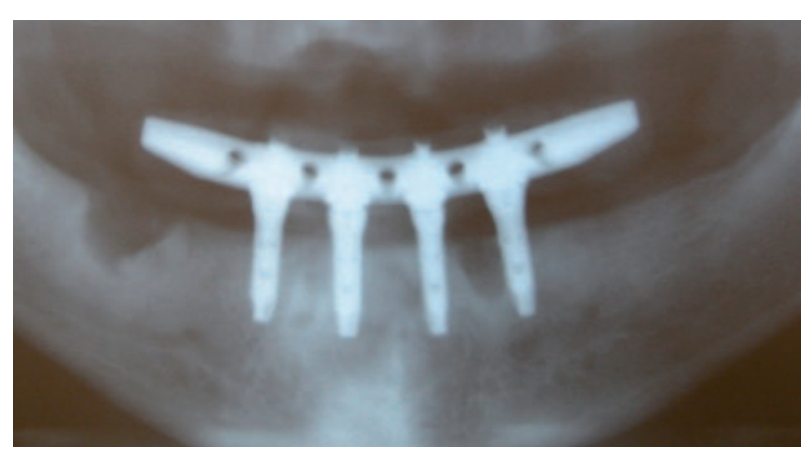

Figura 5. Radiografía panorámica pos operatoria.

Figure 5. Post operative panoramic radiograph.

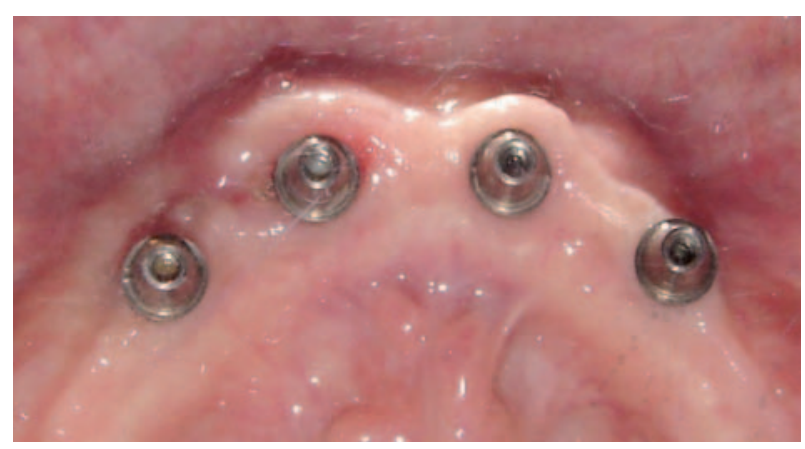

Figura 6. Remoción de prótesis y control de los implantes des-

Figure 6. Removal of prosthesis and control of the implants after 14

groove bone regeneration after the removal of the cementoblast fragments. In this case when Rog was used the results were not good.

The prosthetic protocol used was the Immediate Loading Speed Master System, following the protocol proposed by Vaconecellos et al, which is the same as the principles presented by the Branemark Novum System.

Despite some differences between the protocols, the basic concept of prevention of implant micro movement sited by Skalak was respected. All of the implants were installed using 
tuar al tiempo de remoción de los cementoblastomas. La aplicación de este protocolo para otros casos similares requiere de una cuidadosa planificación.

\section{Bibliografía}

1. Albrektsson T, Zarb G. Determinants of correct clinical reporting. Int / Prothodont 1998;11:517-21.

2. Brånemark PI. The Brånemark Novum Protocol for Same-Day Teeth: A Global perspective. Berlin: Quintessenz, 2001:16-20.

3. Brannon RB, Fowler CB, Carpenter WM, Corio RL. Cementoblastoma: An innocuous neoplasm? A clinicopathologic study of 44 cases and review of a literature with special emphasis on recurrence. Oral Surg Oral Med Oral Pathol Oral Radiol Endod 2002;93:311-20.

4. Brunski JB. Avoid pitfalls of overloading and micromotion of intraosseous implants [interview] IN: Tarnow DP, Emtiaz S, Classi A. Immediate Loading of Thread Implants at Stage 1 Surgery in Edentulous Arches Ten Consecutive case reports With 1 and 5-year data. Int J Oral Maxillofac Implants 1997;12:319-24.

5. Camargo PM, Pirih FQ, Wolinsky LE, Kamrath H, White SN. Clinical repair of an osseous defect associated with a cemental tear: a case report. Int J Periodontics Restorative Dent 2003;23:79-85.

6. Cameron HU. The effect of movement on the bonding of porous metal to bone. In: Tarnow DP; Emtiaz S, Classi A. Immediate Loading of Thread Implants at Stage 1 Surgery in Edentulous Arches Ten Consecutive case reports With 1 and 5-year data. Int J Oral Maxillofac Implants 1997;12:319-24.

7. Capelli M, Zuffetti F, Del Fabbro M, Testori T. Immediate Rehabilitation of the completely edentulous Jaw with fixed prostheses supported by either upright or tilted implants: A multicenter clinical study. Int J Oral Maxillofac Implants 2007; 22:639-644.

8. Chen JH, Lin GC. Clinical study of benign cementoblastoma: a report of 32 cases. Shangai kou Qiang Yi Xue 1997;6:78-80.

9. Fleming P, Ryan D. Benign cemetoblastoma: a case report. Acta Stomatol Belg 1990;87:209-15.

10. Gallucci GO, Bernard JP, Bertosa M, Belser UP. Immediate Loading with screwretained provisional restorations in edentulous jaws: The pick up technique. Int J Oral Maxillofac Implants 2004;19:524-33.

11. Horiuchi K, Uchida H, Yamamoto K, Sugimura M. Immediate Loading of Branemark System Implants Following Placement in Edentulous patients: A Clinical Report. Int J Oral Maxillofac Implants 2000;15:824-30.

12. Jimenez-Lopez V. Proteses Sobre Implantes: Oclusão, Casos Clínicos e Laboratório. São Paulo, Quintessence Editora Ltda, 2a edição, 1996.

13. Pacifici L, Tallarico M, Bartoli A, Ciconetti A. Benign Cementoblastoma: A clinical case of conservative surgical treatment of the involved tooth. Minerva Stomatol 2004;53;685-91.

14. Skalak R. A Brief essay on the philosophy of one-step versus a two-step procedure for osseointegrated fixture-supported dental prosthesis. In: Branemark PI. The Branemark Novum Protocol for Same-Day Teeth: A Global perspective. Berlin: Quintessenz 2001;16-20.

15. Schnitman PA, Whorle PS, Rubenstein JE, da Silva JD, et al. Ten-Year Results for Branemark Immediately Loaded Fixed prostheses at Implant Placement. Int J Oral Maxillofac Implants 1997;12:495-503.

16. Sumer M, Gunduz K, Sumer P, Gunhan O. Benign Cementoblastoma: A case report. Med Oral Patol Oral Cir Bucal 2006;11:E 483-5.

17. Strub JR, Wotkowski S, Einsele FT. Aspectos Protéticos em Implantodontia. São Paulo. Quintessence Editora Ltda, 1a.edição, 1997.

18. Tarnow DP, Emtiaz S, Classi A. Immediate Loading of Thread Implants Stage 1 Surgery in Edentulous Arches Ten Consecutive case reports With 1 and 5- Years data. Int J Oral Maxillofac Implants 1997;12:319-24.

19. Testori T, Del Fabbro M, Szmuckler-Moncler S, Francetti L, Weinstein RL. Immediate Occlusal Loading of Osseotite Implants in The Completely Edentulous Mandible. Int J Oral Maxillofac Implants 2003;18:544-51.

20. Vasconcellos DK, Bottino MA, Saad PA, Faloppa F. A New Device in Immediately Loaded Implant in The Edentulous Mandible. Int J Oral Maxillofac Implants 2006;21:615-22. an initial $45 \mathrm{Ncm}$ anchor and Feruized with a rigid suprastructure.

Cementing the titanium supra structure over the components was based on the studies presented by jimenezLopes 9 and STRUB et al 13 of prosthetic passivity. JimenezLopes 9 proved to be effective and resistant to the cement to fix the components to the prosthesis. The Alba junior et al. studies verified the results of these authors. Some authors have clinically compared the success of the proposed cementation of the suprastructure over the titanium components.

The presentation of this case has shown that the use of Osseo integrated immediate loading implants it is possible to carry out the removal of the cementoblasts. The application of this protocol for other similar cases requires careful planning. 